\title{
3D çap texnologiyaları və onların yaratdığı təhlükələr
}

\author{
Anar Səmidov $^{1}$; Zülfiyyə Hənifəyeva ${ }^{2}$ \\ ${ }^{1,2}$ AMEA İnformasiya Texnologiyaları İnstitutu, Bakı, Azərbaycan \\ Ianarsamidovegmail.com; ${ }^{2}$ zulfiyyehenifeyeva@gmail.com
}

\begin{abstract}
Xülasə - Müasir dövrdə 3D çap geniş yayılmışdır. Artıq 3D çapa cəmiyyətin müxtəlif sahələrində - təhsildə, tibdə, inşaatda, dizayn sahəsində, kosmik məlumatların öyrənilməsində, hərbidə və s. rast gəlmək olar. 3D çapın faydaları ilə yanaşı mənfi təsirləri də rol almaqdadır. Məqalədə 3D çapın imkanları və tətbiq sahələri göstərilmiş, eyni zamanda 3D printerlərin yaratdığı təhlükələr araşdırılmışdır.
\end{abstract}

Açar sözlar - 3D printer, 3D silah, 3D texnologiya, sinterlamo.

\section{GİRIŞ}

Son 500 ildə surətçıxarma çox sürətlə inkişaf etmişdir. Bu texnologiyanın inkişafı mətbəələrin naşirləri əvəz etməsi ilə nəticələnmişdi, zavod və fabriklərdə eyni hərəkəti icra edən işçi əməyinin robotlarla əvəz olunmasına səbəb olmuşdu. Surətç1xarma hər zaman aktual olub. Keçmişdə sənətkarlar tərəfindən hazırlanan nadir nüsxəli əşyaların, sonralar, zavod və fabriklərin yaranması nəticəsində kütləvi istehsalına başlanıldı. Nəticədə məhsulları ucuz qiymətə əldə etmək mümkün oldu.

Hal-hazırda yeni sənaye inqilabı ərəfəsindəyik. İndi hər kəs öz evində kompüterdən istifadə edərək, istənilən filmin, musiqinin, fotonun sürətini çox asanlıqla çıxara bilir. Artıq 3D printerlər mövcuddur. $\mathrm{Bu}$ printerləri hər kəs əldə edib öz evində istənilən fiziki obyektin üçölçülü modelini çap edə bilər. Yaxın gələcəkdə 3D printerlərlə adi printerlərdə kağız çap etdiyimiz kimi istənilən bir əşyanı, geyimi, hətta insan orqanını çap etmək mümkün olacaq .

3D texnologiya müasir comiyyətin bir çox sferalarında tətbiq edilir. Bu texnologiyaların çox sürətlə təkmilləşdirilməsi 3D printerlərin elm və texnikanın ən müxtəlif sahələrində istifadəsinə imkan verir.

\section{3D PRINTER: İMKANLARI, TӘTBİQ SAHӘLӘRİ}

3D çap, günümüzdə böyüyən sənayelərdən biridir, çünkü bu qurğular oyuncaqlar, aksesuarlar, idman ayaqqabıları, silahlar, maşınlar və hətta ürək kimi orqanlar çap etmək mümkündür. Oslində 3D çap yeni bir texnologiya deyil. Onun tarixi təxminən 30 il əvvəl ABŞ-da başlayıb, fotopolimerləşə bilən kompozit materiallardan həcmli obyektlərin yaradılması prosesi icad olundu. $\mathrm{Bu}$ texnologiya stereolitoqrafiya adlanırd1 [1]. Daha sonra, müxtəlif materiallardan üçölçülü modellərin meydana gəlməsi öyrənildi, 3D çapın digər üsulları ortaya çıxdı, əsasən sənaye və yüksək ixtisaslaşmış istehsalda istifadə edildi və bunların hamıs1 prototiplənmə adlanırd1.
3D çap texnologiyası hər hansı bir rəqəmli görüntünü "evdə" əks etdirilə bilən həcmli fiziki bir obyektə çevirməyə imkan verir. Laylar üzrə modelləşdirmə 1980-ci illərin sonlarında icad edilmişdir və 1995-ci ildə "3D printer " (3D çap) konsepsiyaları ortaya çıxd1.

Üçölçülü çapetmə, prinsipcə sinterləmə ilə oxşar olan birləşdirmə metodu ilə işləyir və fiziki əsasına görə adi çapetməyə (plotter üsulu) bənzədiyindən üçölçülü çapetmə $3 D$ Printing adlanır [2].

3D printer rəqəmsal fayllardan fiziki obyektlər yaradan yeni bir texnologiyadır. 3D çap sahəsində son texnoloji nailiyyətlər tibb sahəsində bu texnologiyadan istifadənin artmasına səbəb olmuşdur.

Hazırki dövrü 3D əsri adlandırmaq olar. 3D texnologiyaların sürətlə yayılması insanları daha rahat bir şəraitlə təmin edir. 3D çap müxtəlif sahələrdə, o cümlədən, təhsildə, tibdə, zərgərlikdə, inşaatda, tekstil sahəsində, oyuncaq və suvinirlərin istehsalında, geoinformasiyanın alınmasında və s. tətbiq edilir:

- Tohsildo - 3D çap texnologiyasının tahsildo istifadəsi, tahsil müəssisasina sinif otaqları üçün gözal syani vasaitlar alda etmak imkanı verir. Tahsil müassisalarinin $3 D$ printerlarla tachiz edilmasi tahsil prosesinin samaraliliyinin artırllmasl, şagirdlarin va talabalarin biliklarini süratli şəkilda artırmasına kömak edacayi ehtimal olunur [3].

- Tibbda - 3D printerlarin tibbda tatbiqi insan hayatını xilas etmaya kömak edir. Bela printerlar uğurlu amaliyyatın tamin edilmasi üçün insanın skeletinin tam surotini yarada bilir. $3 D$ çap protez vo stomatologiya sahosinda daha geniş istifado olunur. Tibbi üç ölçülü modellar canlı hüceyralar do daxil olmaqla müxtalif materiallardan hazırlana bilar [4].

- Zargarlikdo - Malumdur ki, zargarlik istehsalında on çox vaxt aparan va böyük bir sarmaya talab edan prosedur qaliblarin yaradılmasıdır. 3D printerlarin meydana galmasi ila, zargarlar daha avval xüsusi bir proqramda hazırlanan zorgarlik modellarinin qaliblarini süratla artırma fürsatina sahib oldular.

- Tekstilda - 3D texnologiyal printerlar tadricon geyim istehsalı sahosindo do istifado olunmağa başlad, ilk növbada yüksak moda modellari yaradıldl. 3D çap texnologiyası bir neçə farqli materialdan istifado 


\section{“İformasiya tohlükosizliyinin aktual multidissiplinar elmi-praktiki problemlori” IV respublika konfransı, 14 dekabr 2018-ci il}

etmokla geyimin bir predmetini hazırlamağa imkan verir. Bu yanaşma hazırlanan mohsulun keyfiyyat vo kamiyyat baxımından problemlarini hall etmaya şarait yaradır.

- Xoritorin yaradılmasında - 3D printerlardon istifado edarak, arazinin manzarasini daqiq aks etdiran va hatta müxtalif landşaftların yerlaşmə saviyyalarini göstaran iri rangli xaritalar yaratmaq olar [5].

- Qablaşdırmada - Üçölçülü printerlar şüşə va flakonların orijinal formasının nümuns maketini düzəltməyə imkan verir. Nümunələr bütün dizayn elementlari, o cümladan etiketlar, barkodlar, marka adlar da daxil olmaqla rongarong ola bilor. Hazır istehsal qablaşdırma modellari kütlovi istehsala başlamazdan avval müştariya göstarila bilar. 3D nümunənin üstünlüyü göz qabağındadır: müştəri paketa toxunur, rangini va digar xüsusiyyatlarini qiymatlandirir.

Qeyd etmok lazımdır ki, 3D texnologiyaları uzunmüddətli və həcmli modellər yaratmaq üçün bir çox qurum tərəfindən uğurla istifadə edilmişdir. Məsələn, şəffaf materialların modellərinin mövcudluğu kompleks mexanizmlərin daxili fəaliyyətinin öyrənilməsini çox asanlaşdırır. $\mathrm{Bu}$ baxımdan tibb sahəsində qazandıqları müvəffəqiyyətlər daha cəlb edicidir. Dünyanın aparıcı ölkələrində cərrahlar insan orqanlarının vəziyyətini daha dəqiq diaqnoz etmək üçün 3D modellərdən istifadə edirlər. Baxılan texnologiyaların istifadəsi tibbin keyfiyyətini əhəmiyyətli dərəcədə yaxşılaşdırdı. Xüsusilə diş protezləri üçün üçölçülü çapın əhəmiyyəti xüsusilə diqqəti çəkir [6]. Böyük Britaniyadan olan alimlər yaxın vaxtlarda gözün torqişasının nümunəsini yarada biliblər. Bu, gələcəkdə daha ağır göz xəstəliklərinə qarşı mübarizə aparmaq imkanı verən "pis görmə" konsepsiyasını məhv edə bilər. Süni donor orqanları, müalicə edilə bilməyən xərçəng xəstəliklərinə qarş1 mübarizədə kömək edəcək və transplant əməliyyatları qlobal olaraq asanlaşdıracaq.

Üçölçülü çap yalnız titan implantları deyil, həm də strukturu əslinə maksimal oxşar olan sümük modelləri yaratmağa imkan verir. $\mathrm{Bu}$ texnologiya transplantasiya prosesini daha sadə və təhlükəsiz edə bilər.

\section{3D ÇAPIN TӘHLÜKӘLӘRİ}

3D çap, avtomobillər, aerokosmik sənaye, tibbi tədqiqatlar, istehsal və xidmət sənayesi daxil olmaqla bir çox sektorda sənaye paradiqmalarını dəyişdirən əsas texnologiya halına gəlmişdir. Lakin, üçölçülü çap, rəqəmsal üç ölçülü obyektlər üçün müəllif hüquqları məsələlərini ortaya çıxarır, çünki obyekt məlumatları həm onlayn, həm də fiziki şəkildə dərc edilə bilər. Bu hal, üçölçülü çap mühitində intellektual mülkiyyətin qorunmasına aiddir. Daha sonra mövcud müəllif hüquqlarının qorunması texnologiyaları, eləcə də skriptlər və digər müxtəlif aspektləri göstərmək olar. Vitrual mühitdə üç ölçülü obyektlərin çap1 zaman1 intellektual mülkiyyətin müəllif hüquqlarının təmin olunması vacibdir [7].
Lakin 3D printerlərin təhlükəsizliyində çox vacib bir qüsur aşkarlandı. Kaliforniya Universitetinin elm adamları qurğunun çap prosesi zamanı çıxardığı səsləri sadə bir səs yazma qurğusu vasitəsiylə qeydə alıb sonradan dinləyərək, printer tərəfindən hazırlanmış məhsul haqqında məlumat əldə ediblər. Belə ki, printerin çap başlı̆̆ının çap prossesi zamanı onun hərəkətini izləyərək yaratdığ 1 səs-küyə əsasən hans1 dizayn formasının çap olunduğunu başa düşmək çox asandır. Başqa sözlə, hər hansı bir intellektual məhsulu oğurlamaq üçün əməliyyat zamanı printerə yaxın bir smartfon və ya digər səs yazma qurğusu qoymaq kifayətdir. 3D printer işinin səs yazısından istifadə edərək, komanda çap olunmuş obyektin demək olar ki, 90\% -ini dəqiqliklə yenidən yaratmağa nail olurlar. Bu faktın özü üçölçülü çapdan istifadə edən şirkətlər üçün məhsulları sənaye casusluğundan qoruma barədə düşünməyə kifayət edir [8].

3D çapdan istifadənin daha da təhlükəli tətbiqləri var. Məsələn, 3D printerlərdən istifadə etməklə silah istehsal etmək imkanı var. Belə ki, 2013-cü ildə amerikalı Kodi Uilson 3D çapdan istifadə edilən bir ədəd tapança modelini yaratdı və İnternetdə yerləşdirdi [9]. Bu silahlar adi odlu silahla müqayisədə nisbətən ucuz və asanlıqla başa gəlir. İlk iki gündə Uilson modelinin təsvirləri yüz minlərlə insanları cəlb etmişdir. Təsadüfi deyil ki, ABŞ, silah istehsalı üçün üç ölçülü çapdan istifadəni qadağan hesab edirdi. Filadelfiya odlu silahları qadağan etməyə qərar verən ilk şəhəridir. Bu qərar Filadelfiya Şəhər Şurası tərəfindən 21 noyabr 2013-cü ildə qəbul edilmişdir (şəhərdə 3D printerlərin sayının dəqiqliyi, silahın çap həcmi və onun istifadəsi Filadelfiya səlahiyyətlilərinə aid edilməmişdir) [9]. 27 noyabr 2013-cü ildə Solid Concepts şirkəti tarixdə ilk dəfə olaraq tam metaldan kalibri 45 ACP olan M-1911 hərbi silah modelini "çap etdirdi". Silah, paslanmayan poladdan 17-4PH və İnconel 625 markalarının sintezindən yaradılmışdır və nəticədə alınan silahın sınaqları standartlara tamamilə uyğun olaraq olduqca yaxşı performans göstərmişdir [10].

Dünyada 3D silahların qanunsuz istehsalı getdikco genişlənir. Yaponiya "çap olunmuş silah" istehsalı və saxlanması üçün ilk hökmü verdi, İngiltərədə isə polis 3D printerləri istifadə edərək silah istehsal etməyə cəhd edənləri ələ keçirdi.

Təhlükəsizlik mütəxəssisləri, cinayətkarların aeroportlarda və oxşar yerlərdə təhlükə aşkar edən skanerlərdən qaçmaq üçün bu cür silahlardan istifadə edəcəklərindən çox qorxurlar.

3D printer vasitəsi ilə çap olunan silahlar həqiqətən də hər şeyə qabildir və bu da onu deməyə əsas verir ki, mütəşəkkil cinayətkar dəstələr son texnologiyalardan istifadə edərək bu cür silahlardan əldə edə bilərlər. Eyni zamanda belə texnologiyaları küçədə də əldə etmək olar. Cinayətkarların evdən çıxmadan silah istehsalı ilə məşğul olma, sonra bu silahları cinayətkar qruplara satmaq imkanı var.

3D-texnologiyanın fəal tətbiqinin qarşısını alan amil onların böyük maliyyə vəsaiti tələb etməsidir. Bu sahədə məşğul olan alimlərin əsas məqsədi $3 \mathrm{D}$ printerlərin dəyərini azaltmaq və ev şəraitində əlçatan etməkdir. Belə ki, hər kəs belə bir printerə uyğun maddələr doldurur, nəticədə telefon, 


\section{“Informasiya tohlükosizliyinin aktual multidissiplinar elmi-praktiki problemlori” IV respublika konfransı, 14 dekabr 2018-ci il}

qab, qida və digər faydalı məhsullar əldə edə bilər. İstehsal metodlarında belə fundamental dəyişikliklər iqtisadiyyata təsir etməyə bilməz. Sənayenin bu cür inkişaf xüsusiyyətləri mütəxəssisləri dərindən düşündürür $\mathrm{ki}$, potensial alıcılar fabriklərdə istehsal olunan əşyaların alınması əvəzinə, öz evlərində 3D printerlə lazım olan əşyaları müstəqil hazırlamağ1 üstün tutacaqlar [11]. Digər məsələ isə məhsulların primitiv üsulla hazırlaması prosesidir. Bütün bunlar 3D çapın tətbiqi imkanlarının çox kiçik bir hissəsidir. $\mathrm{Bu}$ texnologiya gündən-günə təkmilləşir, onun imkanlarından cəmiyyətin müxtəlif sahələrində istifadə edilir. Yeni imkanlar isə yeni mütəxəssislərə tələbatı artırır. $\mathrm{Bu}$ səbəbdən təhlükəsizlik məsələlərinə riayət olunmalıdır. 3D texnologiyalarla işləməyi bacaran, təhlükəsizlik biliklərinə yiyələnmiş peşəkar mütəxəsislərə ehtiyac vardır.

\section{NəTİCO}

Beləliklə, üçölçülü çap texnologiyasından istifadə XXI əsrdə insan fəaliyyətinin bütün istiqamətlərində tibb, tikinti, qida sənayesi, yüngül və ağır sənaye, hərbi sənaye, maşınqayırma (təyyarə istehsalı və raket istehsalı daxil olmaqla), yerətrafi fəzanın mənimsənilməsi, elmi fəaliyyət, incəsənət və s. sahələrində geniş perspektivlər qazanmışdır. Ominliklə demək olar ki üçölçülü texnologiyaların tətbiqi, xüsusilə müxtəlif texniki qurğuların (məsələn, smartfon), silah, geyim, hətta həyati vacib orqanların və ərzaq məhsullarının çap imkanları barədə suallara kifayət qədər müsbət cavab verməyə imkan verəcək. Bu cür texnologiyanın sürətli inkişafı "möhtəşəm gələcək" haqqında proqnozlar verməyə xidmət edir, məsələn, evlərin tikilməsi (hətta bütün şəhər), yerətrafı orbitdə müxtəlif obyektlərin qurulması, insan bədəninin hissələrinin yaradılması 3D çapdan istifadə edərək skeletin sümüklərinin, ürəyin, qaraciyərin və digər mühüm orqanların yenidən bərpası gələcək nəsil alimlərin vəzifəsidir vo biz inanırıq ki, gec-tez bu proses baş tutacaq[12].

$\mathrm{Bu}$ texnologiyanın nə qədər ümidverici yaxşı olmasına baxmayaraq, onun sosial sferaya gətirə biləcək pis nəticələrini unutmamalıyıq. Heç kəs bizə kütləvi qırğın silahlarının çap edilməyəcəyi kimi bir zəmanət vermir.

3D çapdan həm yaradıcı, həm də dağıdıcı məqsədlər üçün istifadə ediləcəyini nəzərə alsaq bu cür texnologiyalar bir sira qanunlar, habelə beynəlxalq normalar və qaydalara riayət olunmasına ciddi tənzimləmə tədbirləri tələb edir. $\mathrm{Bu}, 3 \mathrm{D}$ texnologiyanın idarə edilməsinin və onların gələcək inkişafının tərkib hissəsi olmalıdır.

On yaxşı halda hökumət və hüquq-mühafizə orqanları, üç ölçülü printerdə çap olunan silahlara birbaşa qadağa qoymalıdır. Eləcə də silah istehsalı üçün lazım olan faylların yaradılması, paylanması və saxlanması ilə bağlı qanun qəbul edilmosidir.

\section{ӘDӘBIYYYAT}

[1] Как Чак Халл изобрел 3D-печать - URL: https://habr.com/company/smileexpo/blog/420713/

[2] Энциклопедия 3D-печати. - URL: http://3dtoday.ru/wiki/

[3] А.П. Сябренко, Ю.С. Сахалтуева, С.Е. Юленков, В.С. Тынченко
“Использование технологии 3D-печати в образовании будущих инженеров"

[4] Devin Peek and Elizabeth Stark "Three Dimensional Printing: Modern Medical Applications" Graphic Communication Department College of Liberal Arts California Polytechnic State University 2010

[5] М. Н. Лысыч, М. Л. Шабанов, В. В. Романов "Области применения технологи й 3D печати" Современные наукоемкие технологии. 2014, № 12 (часть 2), 165-169

[6] A.F. Səmidov, E-tibb və 3D Texnologiyaları / A.F. Səmidov // "Elektron tibbin multidissiplinar problemləri" I respublika elmi-praktiki konfrans1. - Bak1, 2016. - S. 127-129.

[7] The dangers of 3-D printing - URL: https://searchstorage.techtarget.com/opinion/The-dangers-of-3Dprinting

[8] Anyone Can Steal 3D-Printed Products by Just Listening to The Sounds The Printer Makes - URL: https://www.sciencealert.com/anyone-cansteal-3d-printed-products-by-just-listening-to-the-sounds-the-printermakes

[9] В. Сычев Подписано в печать. Американские власти испугались пистолета «из принтера» http://lenta.ru/articles/2013/05/13/printed/

[10] Американцы «напечатали» из металла армейский пистолет. http://lenta.ru/news/2013/11/08/gun1911/

[11] Н.В. Кушнир, А.В. Кушнир, А.М.Геращенко, В.А.Терьякин«3Dпринтеры: технологии трехмерной печати и их влияние на общество и экономику» научные труды кубгту, №5, 2015 год

[12] 3D принтеры в медицине, их настоящее и будущее - URL $\mathrm{http} / / /$ medicena.ru/blogpost/3d-printeryi-v-meditsine-ih-nastoyashheei-budushhee/

\section{D PRINTING TECHNOLOGIES AND DANGERS CAUSED} THEM

\author{
Anar Samidov ${ }^{1}$, Zulfiya Hanifayeva ${ }^{2}$ \\ ${ }^{1,2}$ Institute of Information Technology of ANAS, \\ Baku, Azerbaijan \\ Ianarsamidov@gmail.com; ${ }^{2}$ zulfiyyehenifeyeva@gmail.com
}

Abstract - 3D printing is widely spread in modern era 3D printing is used in different areas of the society today; in education, medicine, construction, design, studying cosmic information, military etc. There are negative impacts of 3D printing with its useful sides. The opportunities and application areas are shown at the article and at the same time dangers 3D printers caused are researched.

Keywords - 3D printer, 3D gun, 3D technology, sintering. 